\title{
UCLA
}

Mester

Title

Mester XXXIX Introduction

Permalink

https://escholarship.org/uc/item/5j7363rt

Journal

Mester, 39(1)

Author

Venegas, Gabriela

Publication Date

2010

DOI

10.5070/M3391010083

Copyright Information

Copyright 2010 by the author(s). All rights reserved unless otherwise indicated. Contact the author(s) for any necessary permissions. Learn more at https://escholarship.org/terms 


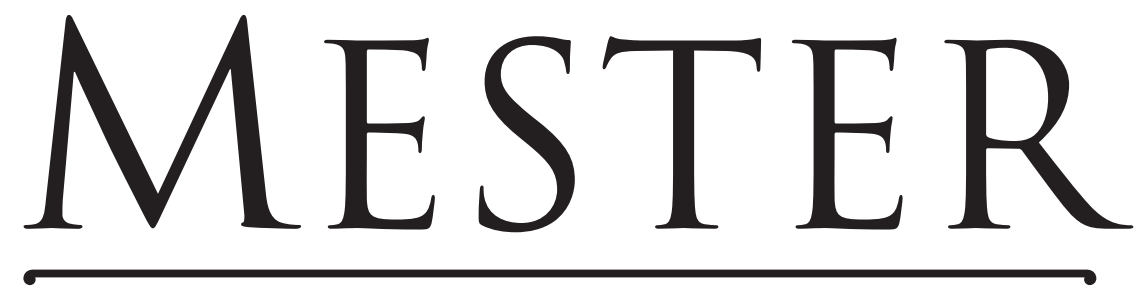

FOCUS: ANDEAN STUDIES
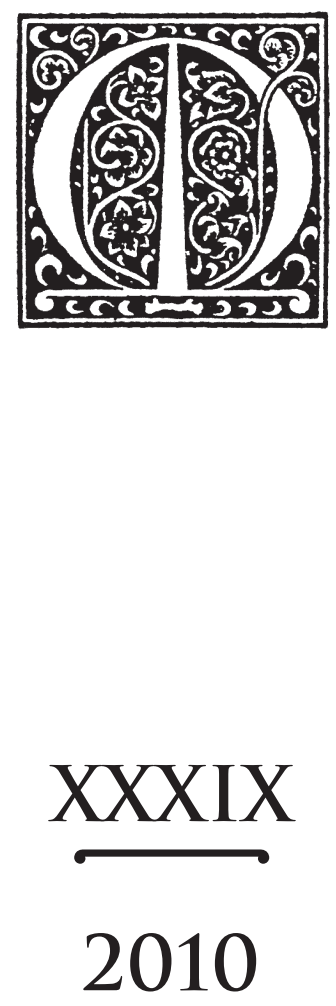

U N I V E R S I T Y O F C A L I F O R N I A, L O S A N G E L E S 
EDITORIAL BOARD

Editor-in-Chief

Gabriela Venegas

Editors
Bethany Beyer
Hilary Danailova
Susannah R. Drissi
Marie Enright
Victoria Garrett
Covadonga Lamar Prieto
Brenda Ortiz-Loyola
Wanderley Reis da Silva
Rachel VanWieren

Contributing Editors

Faculty Advisor

Vanessa Fernández

Efraín Kristal

Moira Nardi

Therí Alyce Pickens

Layout

Guest Contributing Editors

William Morosi

Román Luján

Belén Villarreal

International Associate Editor

Maria Bitarello

Mester (ISSN 0160-2764) is the graduate student journal of the Department of Spanish and Portuguese, University of California, Los Angeles. It is published annually online (http:// escholarship.org/uc/ucla_spanport_mester) and in print with the generous assistance of the UCLA Department of Spanish and Portuguese, the Del Amo Foundation, and the UCLA Graduate Students Association.

\section{Submission Guidelines:}

To be considered for publication, manuscripts should follow the conventions of the latest edition of the MLA Style Manual. It is presumed that all submissions are original research, and not previously published in any other form. Submissions that are being considered by another journal or any other publisher will not be accepted.

An article submission should have no fewer than 15 pages (3750 words) and no more than 25 double-spaced pages (8000 words), including endnotes and Works Cited.

Submissions of reviews for works published within the past year are accepted for the following categories: academic books, linguistics, film and fiction. Reviews should be between 500 and 1500 words in length. Publishers and authors are welcome to submit books for possible selection.

Submissions should be made online at http://escholarship.org/uc/ucla_spanport_mester, where full submission guidelines are posted.

All issues of Mester up to Volume 37 are freely available online in their entirety through the Internet Archive at http://www.archive.org/details/mester_journal. Address all correspondence and requests for print copies of issues up to Volume 37 to: Mester, Editor-in-Chief, Department of Spanish and Portuguese, University of California, Los Angeles, Los Angeles, CA 900951532 or mester@ucla.edu. For more information, you may visit http://escholarship.org/uc/ ucla_spanport_mester.

For print copies from Volume 38 going forward, purchase Mester through UC Press: http:// www.ucpress.edu.

Mester is indexed in the MLA International bibliography and is listed in the ISI Web of Science.

Copyright 2010 MESTER.

MESTER is a copyrighted compilation, and all rights are reserved worldwide. Permission to reprint or use full issues of MESTER should be sent to mester@ucla.edu.Permissions to reprint or use individual articles in this volume (MESTER 39) should be directed to the author(s) of the article.

Distributed in association with the University of California Press. 


\section{CONTENTS}

\section{VOLUME XXXIX 2010}

INTRODUCTION

\section{FOCUS: ANDEAN STUDIES}

¿Qué significa ser mujer indígena en la contemporaneidad?

Luz María De la Torre Amaguaña

La degradación del voseo en el siglo XVI: análisis

de un documento indiano de 1565

Ana M. DÍAZ

“No pretendo retratar la realidad. Pretendo interpretar un tema para sacar discusiones que tenemos reprimidas": Una entrevista con Claudia Llosa.

Edward M. Chauca, Rafael Ramírez, and Carolina Sitnisky

Guillermo Calderón en conversación: "Chile como nación puede acabarse"

Catalina Forttes ZalaquetT

Vallejo ante el pueblo: intelectual, masas y el camino a España aparta de mí ese cáliz

Jorge Coronado

\section{GENERAL INTEREST}

The Essayistic Touch: Saramago's Version of Blindness and Lucidity

KRISTA BRUNE

Borges y el cine: imaginería visual y estrategia creativa

Jorge Zavaleta BALAREZo

Epistemology and The Lettered City: Ángel Rama,

Michel Foucault and Ibn Khaldun

Cora Gorman Malone

A Conversation with Andrew Brown: Mashing Up Latin American

Literature, Science, Technology, and the Post-human

Victoria Garrett and Rachel VanWieren 


\section{BOOK REVIEWS}

Martinez, Carlos, Michael Fox and JoJo Farrell.

Venezuela Speaks! Voices from the Grassroots.

Oakland, CA: PM Press, 2010. 343pp.

Michelle Leigh Farrell

Torrecilla, Jesús. Guerras literarias del XVIII español: la modernidad como invasión. Salamanca: Ediciones

Universidad de Salamanca, 2009. 172pp.

DANIEL H. BROWN

CONTRIBUTORS 


\section{Introduction}

We are very proud to present Mester XXXIX 2010, the culmination of two main objectives that will take the journal on a new path: first, Mester is now an open-access journal that prints on demand and second, online tools that manage manuscripts' submission and evaluation will allow for a more professional and flexible process. These objectives were made possible by joining the eScholarship Repository of the California Digital Library. With the support and encouragement of the UCLA Department of Spanish and Portuguese faculty, the UCLA librarians Bonnie Tijerina and Angela Riccio, the eScholarship technical support team, past Editors-in-Chief Laura Lee (Mester vol. XXXVII) and Lizy Moromisato (Mester vol. XXXV), this year's Editorial Board, and especially the invaluable help from the Graduate Student Association Publications Director Stacey Meeker, we were able to understand the advantages and complexities of switching from a subscription-based distribution system to an open-access journal that prints only on demand. Our current editorial team was, among other things, pleased to choose and support the "green" option, and ahead we went.

The collection of articles, interviews, and book reviews selected for Mester XXXIX 2010 are a combination of Focus on Andean Studies and General Interest. The Andean region, source of a rich literary tradition and juncture of many different cultures, is focus of a special section. As different voices are gaining more power to represent themselves in the political and socio-economical arenas, its art (literature, film, theatre) needs in turn to be studied through frameworks that acknowledge them. This special section provides a space for some of the new ideas and critical approaches necessary to the understanding of Andean cultures and their literary production. Therefore, we are very proud to open Mester XXXIX 2010 with the essay by Visiting Professor Luz María De la Torre Amaguaña from Otavalo, Ecuador, “¿Qué significa ser una mujer indígena en la contemporaneidad?." Through her research and anecdotes, De la Torre (who was invited to teach courses in Kichwa at the UCLA Department of Spanish and Portuguese) tries to untangle the different historical, socio-economical, political, and psychological threads that make up the identity and value of an indigenous woman today. In this way, De la Torre joins the academic debate and presents to the 
reader interested in Andean literatures and cultures a point of view that firmly rejects any intermediary or ventriloquist, as she calls it. Her article is followed by Ana M. Díaz's "La degradación del voseo en el siglo XVI: análisis de un documento indiano de 1565." Díaz's attempts to demonstrate how voseo, a term once used to express familiarity, became proper only among individuals of low social class in sixteenth- and seventeenth-century Santa Fe (today, Colombia). Moreover, two interesting interviews reveal the ideas behind the work of Peruvian film director Claudia Llosa (whose film La teta asustada was nominated for an Academy Award for Best Foreign Film in 2010), and Chilean playwright Guillermo Calderón (author of Diciembre, Neva, and Clase). To close the Focus section, we are happy to present Professor Jorge Coronado's article, "Vallejo ante el pueblo: intelectual, masas y el camino a España aparta de mí ese cáliz." In it, Coronado affirms that Vallejo's late literary practice corresponds to a transformation in the way he conceptualizes the intellectual's relationship to the masses. Such a transformation is triggered, Coronado argues, by the outbreak of the Spanish Civil War.

Opening the General section, Krista Brune proposes an allegorical reading of two novels by the late José Saramago in "The Essayistic Touch: Saramago's Version of Blindness and Lucidity." Brune demonstrates that Saramago's essayistic proclivity gives him the opportunity to intertwine his fictional work with "political commentary, social observation, and philosophical ruminations." In "Borges y el cine: imaginería visual y estrategia creativa," Jorge Zavaleta Balarezo argues that there is an undeniable link between film and Jorge Luis Borges's work, and attempts to explain how the visual capabilities of the former are translated to the latter's literary narrative. Zavaleta proposes that one of Borges's most acclaimed stories, El jardin de senderos que se bifurcan, is the ideal model for a film script. Cora Gorman Malone contributes to the volume with a reading of Ángel Rama's The Lettered City, which introduces the writings of the fourteenth-century Arab intellectual from the Maghreb, Ibn Khaldun, in order to propose an alternative way to approach Rama's famous essay. In "Epistemology and The Lettered City: Ángel Rama, Michel Foucault, and Ibn Khaldun," Malone suggests that The Lettered City shares certain points of convergence with Khaldun's own attempt at understanding the role of the lettered urban elite in his region, which helps question the adequacy of the Western concept of "modernity" in 
understanding and theorizing Latin America. Furthermore, in a very interesting interview, Professor Andrew Brown opens up about his innovative work on science, literature, and popular culture. Finally, reviews of Venezuela Speaks! Voices from the Grassroots by Carlos Martínez, Michael Fox, and JoJo Farrell, and, Jesús Torrecilla's Guerras literarias del XVIII español: la modernidad como invasión accompany our collection of articles and interviews.

I would like to thank the UCLA Department of Spanish and Portuguese, the Del Amo Foundation, and the UCLA Graduate Student Association for their support. We are also grateful for the support from the UCLA Library that allowed us to digitize almost all of the Mester archive, now available online. Special thanks to faculty advisor Professor Efraín Kristal for his assistance this year. Thanks to the many authors who trusted us with their work. Also, I would like to express my gratitude to the team of Editors, Contributing Editors, Guest Contributing Editors, and the International Associate Editor who helped to bring about this volume and supported the significant changes to our journal. It has been a pleasure to work for Mester this year, and though its transformation as an open-access journal has demanded more work than I was able to envision at the beginning, I am happy to report that the job is done. We hope that the reader enjoys this selection of articles, and also, that the graduate students of our Department interested in joining the ranks of Mester will find both the journal management process to be smoother and the Mester experience to be an enlightening and enjoyable learning opportunity.

Gabriela Venegas Editor-in-Chief Mester XXXIX 

Focus: Andean Studies 
